\title{
Factors affecting energy and nitrogen efficiency of dairy cows: A meta-analysis
}

\author{
H. N. Phuong, ${ }^{*} \dagger^{1}$ N. C. Friggens, ${ }^{*} \dagger$ I. J. M. de Boer, $\ddagger$ and P. Schmidely $\dagger^{*}$ \\ ${ }^{*}$ AgroParisTech, UMR791 Modélisation Systémique Appliquée aux Ruminants, F-75005 Paris, France \\ †INRA, UMR791 Modélisation Systémique Appliquée aux Ruminants, F-75005 Paris, France \\ $\ddagger$ Animal Production Systems group, Wageningen University, PO 338, $6700 \mathrm{AH}$ Wageningen, the Netherlands
}

\section{ABSTRACT}

A meta-analysis was performed to explore the correlation between energy and nitrogen efficiency of dairy cows, and to study nutritional and animal factors that influence these efficiencies, as well as their relationship. Treatment mean values were extracted from 68 peer-reviewed studies, including 306 feeding trials. The main criterion for inclusion of a study in the metaanalysis was that it reported, or permitted calculation of, energy efficiency (Eeff; energy in milk/digestible energy intake) and nitrogen efficiency (Neff; nitrogen in milk/digestible nitrogen intake) at the digestible level (digestible energy or digestible protein). The effect of nutritional and animal variables, including neutral detergent fiber, acid detergent fiber (ADF), digestible energy, digestible protein, proportion of concentrate (PCO), dry matter intake, milk yield, days in milk, and body weight, on Eeff, Neff, and the Neff:Eeff ratio was analyzed using mixed models. The interstudy correlation between Eeff and Neff was 0.62 , whereas the intrastudy correlation was 0.30 . The higher interstudy correlation was partly due to milk yield and dry matter intake being present in both Eeff and Neff. We, therefore, also explored the Neff:Eeff ratio. Energy efficiency was negatively associated with ADF and PCO, whereas Neff was negatively associated with ADF and digestible energy. The Neff:Eeff ratio was affected by ADF and PCO only. In conclusion, the results indicate a possibility to maximize feed efficiency in terms of both energy and nitrogen at the same time. In other words, an improvement in Eeff would also mean an improvement in Neff. The current study also shows that these types of transverse data are not sufficient to study the effect of animal factors, such as days in milk, on feed efficiency. Longitudinal measurements per animal would probably be more appropriate.

Received April 30, 2013.

Accepted July 24, 2013.

${ }^{1}$ Corresponding author: phuong.hongoc@agroparistech.fr
Key words: meta-analysis, energy efficiency, nitrogen efficiency, dairy cow

\section{INTRODUCTION}

Feed efficiency $(\mathbf{F E})$ in dairy production has received increasing attention because it influences not only farm profitability but also losses to the environment. Because feed costs account for more than $50 \%$ of total costs of dairy production (Shalloo et al., 2004), any improvement in FE has a direct effect on the profitability of dairy farms (Britt et al., 2003). Moreover, if nutrients consumed are not converted into milk, body reserves, or a newborn calf, they are excreted into the environment, resulting in emissions of, for example, ammonia, methane, or nitrous oxide (Thomassen et al., 2009). Improving FE can, therefore, be beneficial for both farm profitability and the environmental impact of milk production (Wall et al., 2010; Yan et al., 2010).

Feed efficiency is traditionally defined as the ratio of output to input [e.g., milk produced/DMI $(\mathrm{kg} / \mathrm{kg})$, energy in milk/energy intake (Mcal/Mcal), or nitrogen in milk/nitrogen intake (g/g); Brody, 1945]. An alternative definition of FE is residual feed intake $(\mathbf{R F I} ; \mathrm{kg} / \mathrm{d}$ or Mcal/d), which estimates the difference between actual and predicted intake (Koch et al., 1963; Prendiville et al., 2009). In genetic selection, RFI has been preferred to efficiency expressed as ratios, as selection based on ratios carries disadvantages, such as increased error variance as a proportion of total variance and a strong correlation with component traits, for $\mathrm{FE}$ and milk yield (Wang et al., 1992). Residual feed intake is, by definition, phenotypically independent of component traits, but suffers from the problem of accumulation of errors in the measurements used (Herd and Arthur, 2009). Richardson et al. (2004), for example, stated that only $73 \%$ of the variation in RFI could be explained by biological mechanisms. Despite their obvious importance, in practice, neither FE nor RFI are used extensively due to the difficulties in the field of measuring their components, particularly intake, with a reasonable level of precision (McNaughton and Pryce, 
2007; Moore et al., 2009). A second issue is that FE has commonly been evaluated in terms of energy (or mass), with nitrogen being accounted for only via its energy content (Zamani et al., 2008). However, attention for environmental impact of emissions of $\mathrm{NH}_{3}$ or $\mathrm{N}_{2} \mathrm{O}$, which are related to $\mathrm{N}$ excretion, has increased. Hence, nitrogen efficiency (Neff) should also be considered. In this context, a key question is whether Neff and energy efficiency (Eeff) are affected by the same factors.

Feed efficiency can be measured at metabolizable, digestible, and gross levels of nutrient intake (Veerkamp and Emmans, 1995; Tolkamp, 2010), which we would then call metabolic, digestible, and gross efficiency, respectively. These different measures of FE may lead to different biological or economic interpretations (Blake and Custodio, 1984). Variation in metabolic efficiency indicates primarily differences in partitioning of nutrients between milk production and other life functions. Environmentally speaking, it does not include losses in feces, gases, and urine being excreted. At the other extreme, gross efficiency includes the part of feed that is not available to animals and, as such, it is of limited value for quantifying the variability between animals in efficiency. Efficiency of use of digestible energy (DE) and nitrogen does not consider fecal losses but includes losses in gases, urine, and animal differences in partitioning of nutrients. Digestible efficiency, therefore, makes it possible to not only evaluate the environmental impact of milk production, but also to compare efficiency between animal genotypes in using feed to produce milk. Fecal losses can be estimated easily using feed chemical characteristics or in vitro degradation data (Nousiainen et al., 2009).

Feed efficiency for milk production depends not only on diet composition but also on animal genotype and physiological state (Blake and Custodio, 1984). Genetic potential for milk production and stage of lactation differences modify partition of absorbed nutrients into milk and other life functions. Feed efficiency should, therefore, be studied from both the nutritional and genetic points of view. A better understanding of how nutrients are partitioned has been recognized as being central to maximizing $\mathrm{FE}$ and minimizing environmental impact (Friggens et al., 2011). However, it has become clear later that the available data did not allow the exploration of effect of animal factors on FE. In addition, insight into how Eeff and Neff are correlated and how this correlation changes in different conditions would provide a basis for maximizing or predicting $\mathrm{FE}$ of animals in both energy and nitrogen terms. Using a meta-analysis approach, the current study study explored the correlation between Eeff and Neff, and examined common nutritional factors affecting Eeff and Neff, and their relationships.

\section{MATERIALS AND METHODS}

\section{Literature Search}

A literature search using the Web of Science (http:// thomsonreuters.com/web-of-science/), ScienceDirect (http://www.sciencedirect.com/), and Google Scholar (http://scholar.google.com/) search engines was conducted to create a database for this study. The following keywords were used in different combinations: Eeff, Neff, dairy cows, nutrient utilization, and dairy cow performance. The inclusion criteria in the database were a feed description in terms of ingredients (\%); proportion of concentrate (\%); DMI (kg/d); milk yield $(\mathrm{kg} / \mathrm{d})$; milk fat, protein, and lactose yield (\%); BW (kg); and DIM (d). The chemical composition of the diets in publications was either obtained from the reported laboratory analysis or estimated from NRC (2001), with exceptions of DE and digestible protein, which will be mentioned later in this section.

Only full studies published in peer-reviewed journals were selected (abstracts, conference papers, and review articles were not considered). Eventually, 68 studies (listed in the Appendix) consisting of 306 treatment means that satisfied the above criteria were kept for further analysis.

\section{Efficiency Derivations}

As indicated, FE was defined as the ratio of nutrient output in milk to nutrient input in feed, with a focus on energy and nitrogen (subsequently termed Eeff and Neff). Additionally, inputs were expressed as DE or digestible protein.

Energy efficiency was calculated as the ratio between energy in milk (Mcal/d) and DE intake (Mcal/d):

$$
\text { Eeff }(\%)=\frac{\mathrm{MY}(\mathrm{kg} / \mathrm{d}) \times \mathrm{E} \text { milk }(\mathrm{Mcal} / \mathrm{kg} \text { of milk })}{\mathrm{DMI}(\mathrm{kg} / \mathrm{d}) \times \mathrm{DE} \operatorname{diet}(\mathrm{Mcal} / \mathrm{kg} \text { of DM })},
$$

where MY is milk yield of an animal per day, DE diet is the DE content of the diet, and E milk is the energy content of milk, which is the sum of energy of all milk components including fat, protein, and lactose using the equations suggested by NRC (2001) as follows:

$$
\begin{gathered}
\text { E milk }=\text { milk fat content }(\mathrm{kg} / \mathrm{kg} \text { of milk }) \times 9.29 \\
+ \text { milk protein content }(\mathrm{kg} / \mathrm{kg} \text { of milk }) \times 5.47 \\
+ \text { milk lactose content }(\mathrm{kg} / \mathrm{kg} \text { of milk }) \times 3.95
\end{gathered}
$$

where 5.47, 9.29, and 3.95 are the amounts of energy released from the combustion of $1 \mathrm{~kg}$ of protein, fat, and lactose, respectively (Mcal/kg; NRC, 2001). 
Dry matter intake is calculated per animal per day. The DE diet was estimated using tables from Institut national de la recherche agronomique (INRA, 1988, 2010) and collaboration between INRA and Association Française de Zootechnie (INRA-AFZ; Sauvant et al., 2004). To account for reduced digestibility due to increased DMI, a correction was applied using the equation of Sauvant and Giger-Reverdin (2009):

$$
\begin{gathered}
\mathrm{DE}_{\text {adjusted }}=\mathrm{DE}_{\text {standard }} \times \mathrm{dE}_{\text {adjusted }} ; \\
\mathrm{dE}_{\text {adjusted }}=66.8+20.1 \mathrm{PCO}-3.37 \mathrm{FI},
\end{gathered}
$$

where $\mathrm{DE}_{\text {adjusted }}$ is the $\mathrm{DE}$ after being adjusted for observed feed intake and proportion of concentrate (Mcal $/ \mathrm{kg}$ of DM), DE $\mathrm{E}_{\text {standard }}$ is the $\mathrm{DE}$ value obtained at maintenance level (Mcal $/ \mathrm{kg}$ of $\mathrm{DM}), \mathrm{dE}_{\text {adjusted }}$ is the adjusted digestion coefficient of energy (\%), PCO is the proportion of concentrate (\%), and FI (\%) is the observed feed intake ( $\mathrm{kg}$ of $\mathrm{DM} / \mathrm{d})$ expressed relative to BW $(\mathrm{kg})$.

Nitrogen efficiency was calculated as the ratio between nitrogen in milk (g/d) and digestible nitrogen intake $(\mathrm{g} / \mathrm{d})$ :

$$
\operatorname{Neff}(\%)=\frac{\mathrm{MY}(\mathrm{kg} / \mathrm{d}) \times \mathrm{N} \text { milk }(\mathrm{g} / \mathrm{kg} \text { of milk })}{\mathrm{DMI}(\mathrm{kg} / \mathrm{d}) \times \mathrm{DN} \operatorname{diet}(\mathrm{g} / \mathrm{kg} \text { of DM })},[2]
$$

where $\mathrm{N}$ milk is the nitrogen content in milk, which was either obtained from data (if provided) or calculated by dividing milk CP content by 6.38. Likewise, DN diet is the digestible nitrogen content in the diet, which was either obtained from the study or calculated by dividing digestible protein content in the diet $(\mathrm{g} / \mathrm{kg}$ of $\mathrm{DM})$, obtained from INRA $(1988,2010)$ and INRA-AFZ (Sauvant et al., 2004), by 6.25. The effect of the proportion of concentrate and an increased feed intake on protein digestibility was assumed to be nonsignificant.

It can be clearly seen that MY and DMI appear in both Equations 1 and 2. Thus, we would expect an artifactual correlation between Eeff and Neff, irrespective of any factor related to the diet or animals, with the extent of the correlation depending on how largely MY and DMI numerically contribute to the computations of Eeff and Neff. This should be taken into account when considering factors that affect Eeff and Neff, and also when studying the relationship between Eeff and Neff. Therefore, we decided to look also at the ratio of Neff to Eeff. By analyzing this ratio, the "artifact" of milk yield and DMI is theoretically removed, and other factors that have an influence on the correlation between Eeff and Neff can be more clearly examined. This ratio is shown in Equation 3: $\frac{\text { Neff }(\%)}{\text { Eeff }(\%)}=\frac{\mathrm{N} \text { milk }(\mathrm{Mcal} / \mathrm{kg} \text { of milk }) \times \mathrm{DE} \operatorname{diet}(\mathrm{Mcal} / \mathrm{kg} \text { of DM })}{\mathrm{DN} \operatorname{diet}(\mathrm{Mcal} / \mathrm{kg} \text { of DM }) \times \mathrm{E} \text { milk }(\mathrm{Mcal} / \mathrm{kg} \text { of milk })}$

In Equation 3, $\mathrm{N}$ milk, E milk, DE diet, and DN diet are milk nitrogen content, milk energy content, DE content of the diet, and digestible protein content of the diet, respectively.

\section{Inter- and Intrastudy Correlations Between Eeff and Neff}

The correlation between Eeff and Neff was examined in 2 ways: inter- and intrastudy. The interstudy correlation was simply computed from the observed data of Eeff and Neff, whereas the intrastudy correlation was the correlation after adjustment for the random effect of study. The adjustment for study was made independently for Eeff and Neff, using in each case a mixed model with only the study factor included as a random effect. The residuals of these 2 models represent the intrastudy variability in Eeff and Neff.

\section{Statistical Analysis}

Because the factors that influence FE may be dependent upon each other, this probably results in confounding or bias for later estimations of regression coefficients and explanations (Silvey, 1969). The relationships among independent variables [i.e., NDF, $\mathrm{ADF}$, digestible CP (DCP), DE, PCO, DMI, MY, $\mathrm{BW}$, and DIM] were examined by scatterplot and correlation matrix (Figure 1). Additionally, the residuals versus fitted plots of the models for predicting Eeff, Neff, and the Neff:Eeff ratio from only 1 predictor were performed to check for any potential quadratic effect.

The effect of nutritional or animal variables, including NDF, ADF, DCP, DE, PCO, DMI, MY, BW and DIM, on Eeff, Neff, and the Neff:Eeff ratio was analyzed using multiple linear regression. Milk yield and DMI were not included in the models for predicting Eeff and Eeff, but only in the model of the Neff:Eeff ratio, to avoid artifactual correlations, as previously mentioned. Similarly, DE and DCP were not included in the model for predicting the Neff:Eeff ratio or in the separate models for predicting Eeff and Eeff if they appeared in the denominators of their efficiency calculation. Because the data used in this meta-analysis were gathered from multiple studies conducted over multiple years and in many different conditions, the study effect was considered to be random (St-Pierre, 2001). The random effects were, therefore, incorporated into the 


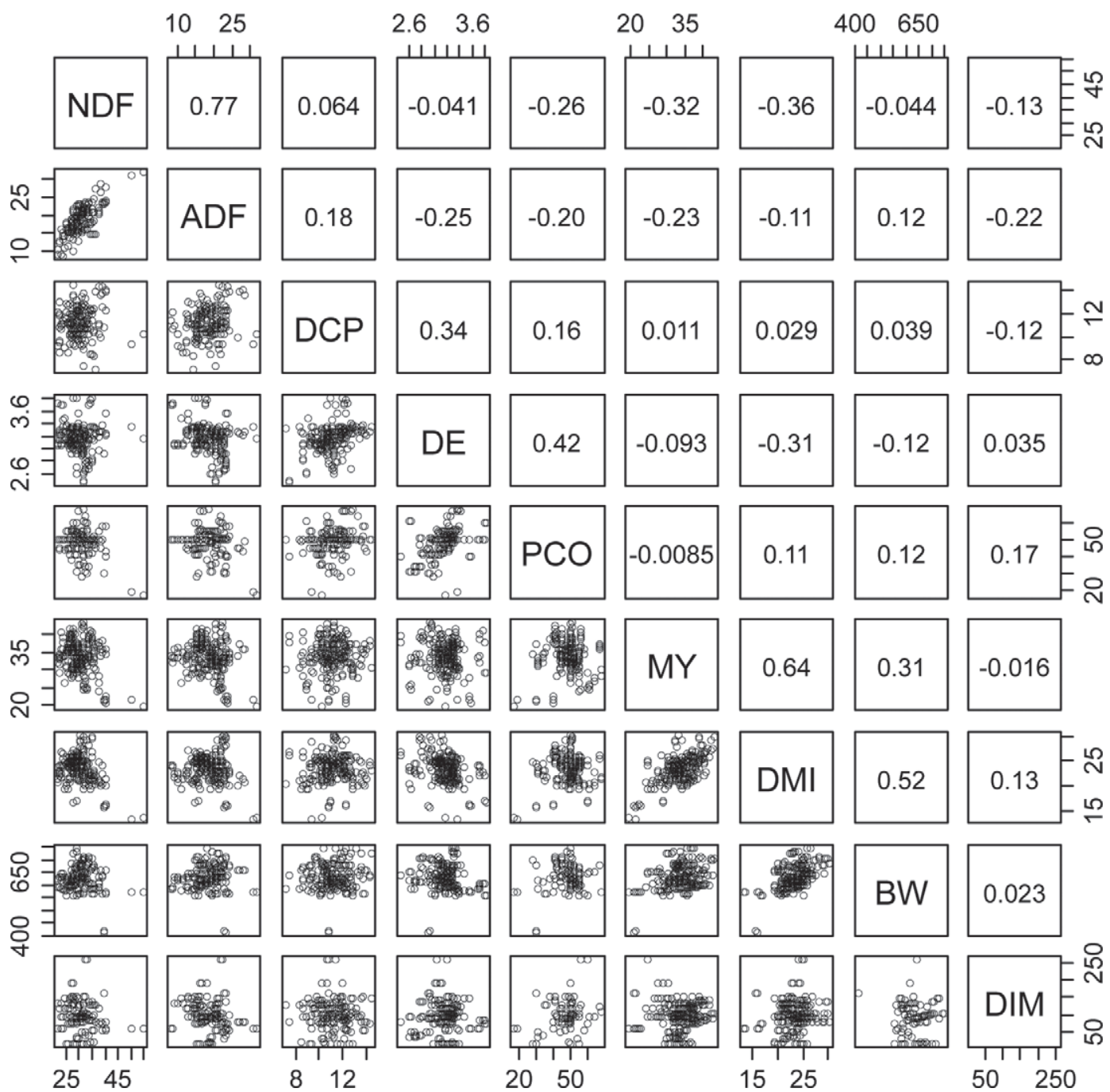

Figure 1. Interstudy correlation matrix between various nutritional and animal variables. $\mathrm{DCP}=$ digestible $\mathrm{CP}(\%$ of $\mathrm{DM}) ; \mathrm{DE}=$ digestible energy content of the diet (Mcal $/ \mathrm{kg}$ of $\mathrm{DM}) ; \mathrm{PCO}=$ proportion of concentrate in the diet (\%); DMI is in kilograms of DM per day; MY = milk yield $(\mathrm{kg} / \mathrm{d})$; BW is in kilograms per cow.

estimation procedure using a mixed effect model. The general form of the mixed model was

$$
\mathrm{Y}_{\mathrm{ij}}=\mathrm{B}_{0}+\mathrm{s}_{\mathrm{i}}+\mathbf{B}_{\mathrm{k}} \mathbf{X}_{\mathrm{ijk}}+\mathrm{e}_{\mathrm{ij}},
$$

where $Y_{i j}$ is the dependent variable (Eeff, Neff, or the Neff:Eeff ratio), $B_{0}$ is the overall intercept across studies, $s_{i}$ is the random effect of the ith study, $\mathbf{B}_{k}$ is a vector of regression coefficients of $\mathrm{Y}$ on the corresponding vector of predictors $\left(\mathbf{X}_{\mathrm{ijk}}\right)$, and $\mathrm{e}_{\mathrm{ij}}$ is the residual error, which was assumed to be normally distributed, with mean 0 and variance $\sigma_{\mathrm{e}}^{2}, \mathrm{i}=1 \ldots 69$ studies, $\mathrm{j}=$ 1 . . 306 observations, and $\mathrm{k}=1$ to 9 predictors. First, the full models including all nutritional and animal variables were run. Second, the least significant variables were removed stepwise according to the degree of significance until only significant variables remained.
To reduce the correlations between intercept and slope, and to make the intercept more meaningful, the prediction variables were centered on their means. The goodness of fit of the models was evaluated internally using the Akaike information criterion (Ngwerume and Mao, 1992). For comparison across models, the coefficient of determination $\left(\mathrm{R}^{2}\right)$ was computed using the following equation from Faraway (2009):

$$
\mathrm{R}^{2}=1-\frac{\left(\mathrm{y}_{\mathrm{i}}-\hat{\mathrm{y}}_{\mathrm{i}}\right)^{2}}{\left(\mathrm{y}_{\mathrm{i}}-\overline{\mathrm{y}}\right)^{2}},
$$

where $y_{i}$ is the ith observed value of efficiency, $\hat{y}_{i}$ is the ith predicted value of efficiency and $\bar{y}$ is the mean of efficiency, $\mathrm{i}=1 \ldots 306$ observations. 
To verify that the study effect was adequately accommodated by fitting it as a random effect, the final model with random effect was compared with a model where the study was included as a fixed effect. This model produced similar results to those of the model with a random study and, therefore, will not be further discussed. Mixed and fixed effect models were performed using respectively the nlme and $1 \mathrm{~m}$ packages of the statistical software $\mathrm{R}$ version 2.15.1 (R Development Core Team, 2012).

\section{RESULTS}

\section{Data Description}

The main ingredients, chemical composition of the investigated diets in this meta-analysis, and their summary statistics are shown in Table 1 . Corn silage and alfalfa silage were the predominant forages, followed by grass silage. The main source of energy from concentrate was corn, including ground corn and highmoisture shelled corn. Soybeans (solvent extracted, soybean expeller, extruded, and heat treated) were the main source of protein supplement. Corn gluten meal, fish meal, and blood and meat meal were the sources of RUP. Sugar cane and sugar beet molasses were used as the supplementation of sugars/energy in supporting microbial protein synthesis. Animal fat and urea were used as supplements of energy and NPN, respectively. The data set showed large variation in the chemical composition of the diets. Digestible protein averaged $11.08 \%$, but ranged from 7.14 to $14.69 \%$. Large variations were also observed in NDF and ADF content, which ranged from 17.80 to $54.50 \%$ and from 8.40 to $31.80 \%$, respectively. The average DE content was 3.16 $\mathrm{Mcal} / \mathrm{kg}$ of DM.

Table 2 illustrates the performance of animals from the studies included in the database. The average DMI was $23.18 \mathrm{~kg}$ of $\mathrm{DM} / \mathrm{d}$, with a range from 13.40 to $30.20 \mathrm{~kg}$ of $\mathrm{DM} / \mathrm{d}$. The highest milk production was $43.28 \mathrm{~kg} / \mathrm{d}$, whereas $16.33 \mathrm{~kg} / \mathrm{d}$ was the lowest recorded milk production from an experiment with cows in late lactation (256 DIM). The earliest DIM recorded was 15 $\mathrm{d}$ and the latest DIM was $256 \mathrm{~d}$. Thirty-eight studies, totaling 153 observations, had DIM $<100$, whereas 30 studies, totaling 147 observations, had DIM $\geq 100$. The mean value of Eeff was $34.09 \%$, whereas Neff averaged $42.63 \%$.

\section{Correlation Between Nutritional and Animal Performance Variables}

Figure 1 shows the interstudy correlations between the dietary and animal variables that were included in

Table 1. Main ingredients and chemical compositions (\% of DM, unless otherwise indicated) of the investigated $\operatorname{diets}^{1}$

\begin{tabular}{|c|c|c|c|c|c|}
\hline Variable & No. of diets & Average & Minimum & Maximum & $\mathrm{SD}$ \\
\hline \multicolumn{6}{|l|}{ Ingredient } \\
\hline Corn silage & 232 & 31.98 & 4.90 & 65.00 & 13.21 \\
\hline Alfalfa silage & 150 & 33.18 & 9.80 & 69.80 & 16.89 \\
\hline Grass silage & 49 & 34.11 & 12.40 & 83.00 & 19.24 \\
\hline Alfalfa hay & 50 & 30.16 & 5.00 & 69.60 & 14.68 \\
\hline Ground corn & 192 & 21.04 & 2.00 & 46.60 & 11.01 \\
\hline High-moisture shelled corn & 90 & 30.16 & 5.20 & 45.70 & 9.07 \\
\hline Corn gluten meal & 69 & 8.32 & 0.81 & 25.85 & 7.52 \\
\hline Soybean meal ${ }^{2}$ & 251 & 8.92 & 0.45 & 19.12 & 4.39 \\
\hline Cottonseed meal & 52 & 7.86 & 1.70 & 15.00 & 4.08 \\
\hline Soybean hulls & 64 & 5.74 & 1.50 & 17.00 & 2.98 \\
\hline Distillers grains & 46 & 7.73 & 1.20 & 22.00 & 5.18 \\
\hline Fish meal & 47 & 1.73 & 0.30 & 5.00 & 1.17 \\
\hline Molasses $^{3}$ & 84 & 3.02 & 0.26 & 10.00 & 2.43 \\
\hline Blood and meat meal & 45 & 2.37 & 0.30 & 6.20 & 1.72 \\
\hline Fat & 56 & 1.52 & 0.02 & 4.80 & 1.01 \\
\hline Urea & 30 & 0.47 & 0.15 & 1.90 & 0.41 \\
\hline \multicolumn{6}{|c|}{ Chemical composition $^{4}(\mathrm{n}=306)$} \\
\hline $\mathrm{CP}$ & 306 & 17.03 & 11.90 & 25.30 & 2.03 \\
\hline NDF & 289 & 30.89 & 17.80 & 54.50 & 4.85 \\
\hline $\mathrm{ADF}$ & 240 & 18.70 & 8.40 & 31.80 & 4.04 \\
\hline $\mathrm{DCP}$ & 306 & 11.08 & 7.14 & 14.69 & 1.37 \\
\hline $\mathrm{DE}^{5}(\mathrm{Mcal} / \mathrm{kg}$ of DM) & 306 & 3.16 & 2.47 & 3.80 & 0.22 \\
\hline
\end{tabular}

${ }^{1}$ Summary statistics from 68 studies reported in the literature.

${ }^{2}$ Soybean meal included soybean meal with 44,48 , or $50 \% \mathrm{CP}$ or solvent extracted, expelled, extruded, and heat-treated soybean meal.

${ }^{3}$ Molasses from either sugarcane or sugar beet.

${ }^{4} \mathrm{DCP}=$ digestible $\mathrm{CP} ; \mathrm{DE}=$ digestible energy content of the diet.

${ }^{5}$ INRA $(1988,2010)$ and Sauvant et al. (2004). 
Table 2. Animal performance characteristics ${ }^{1}$

\begin{tabular}{lcrrrr}
\hline Variable & No. of diets & Average & Minimum & Maximum & SD \\
\hline DMI (kg/d) & 306 & 23.18 & 13.40 & 30.20 & 2.76 \\
MY $(\mathrm{kg} / \mathrm{d})$ & 306 & 35.33 & 16.33 & 43.28 & 5.09 \\
DIM (d) & 302 & 97.00 & 15.00 & 256.00 & 48.00 \\
BW (kg) & 306 & 628.60 & 412.00 & 748.00 & 48.24 \\
Energy efficiency (\%) & 253 & 34.09 & 23.33 & 44.97 & 4.06 \\
Nitrogen efficiency (\%) & 306 & 42.63 & 29.15 & 64.54 & 6.81 \\
\hline
\end{tabular}

${ }^{1}$ Summary statistics from 68 studies reported from the literature.

${ }^{2}$ Milk yield.

the subsequent analyses. It can be seen that fiber fractions (NDF and ADF) were negatively associated with the other variables, including DE, PCO, DMI, MY, and DIM. The digestible protein content of the diets was correlated with DE, PCO, MY, and DIM. Increased DE content of diets depressed DMI, but had a weaker correlation with milk production. Moreover, a highenergy-density diet was related to a large proportion of concentrate $(\mathrm{r}=0.42)$. A strong positive correlation between DMI and MY ( $\mathrm{r}=0.64)$ was found in our analysis, which is consistent with the literature (Roseler et al., 1997; Martin and Sauvant, 2002; Voelker et al., 2002). Positive correlations between BW and DMI or MY imply that bigger animals tended to eat more feed and had a higher milk production.

\section{Correlation Between Eeff and Neff}

The correlation between Eeff and Neff is shown in Figure 2. As expected, due to the presence of milk yield and DMI in both expressions of efficiency, a positive interstudy correlation existed between Eeff and Neff in the unadjusted data $(\mathrm{r}=0.62)$. However, Figure 2a shows that within experiments, an increase in Eeff was not always associated with an increase in Neff (e.g., top right). When the data were presented as intrastudy responses (i.e., they were corrected for the random effect of study), the correlation was reduced $(\mathrm{r}=0.30$; Figure $2 \mathrm{~b}$ ). This is largely due to the greater reduction in range of the data, relative to the reduction in variation.

\section{Factors Affecting Eeff, Neff, and the Neff:Eeff Ratio}

The final models (i.e., including only significant variables) for predicting Eeff, Neff, and the Neff:Eeff ratio are shown in Table 3. Figures 3, 4, and 5 illustrate the plots between observed and predicted values of the models predicting Eeff, Neff, and the Neff:Eeff ratio, respectively. The residual analysis of the above models (plots not shown) was also performed to evaluate the model assumptions for the residuals (for example, equal variance or normality). All final models show a good prediction, with no discernible trend or pattern in the residuals.

\section{Eeff}

Acid detergent fiber had a negative effect on Eeff $(P$ $<0.05)$ : an increase of $10 \%$ in dietary ADF content reduced Eeff by $1.60 \%$. In contrast, PCO affected Eeff in a quadratic way (Table 3). The negative regression coefficient indicates that Eeff improved with a small increase in PCO, but decreased once PCO increased further. Digestible CP, BW, and DIM had no effect on Eeff $(P>0.05)$. At the mean values of $\mathrm{ADF}$ and $\mathrm{PCO}$, Eeff was approximately $34 \%$. In addition, because a strong association existed between NDF and ADF $(r=$ 0.77), a comparison between a model using ADF and PCO and a model using NDF and PCO for predicting Eeff showed that the latter produced a higher Akaike information criterion. Hence, the model including ADF and PCO best predicted Eeff.

\section{Neff}

Table 3 also indicates that increasing dietary ADF and DE contents were negatively associated with Neff. Generally, a $10 \%$ increase in ADF or 1 Mcal increase in DE led to a 5.60 and $6.67 \%$ reduction in Neff, respectively. Nitrogen efficiency was not significantly related to PCO, BW, or DIM.

\section{Neff:Eeff Ratio}

As can be seen from Table 3, the Neff:Eeff ratio was significantly associated with ADF and PCO. The slope decreased with an increase in dietary ADF concentration, whereas it increased if the proportion of concentrate was increased. The Neff:Eeff ratio was not significantly influenced by DMI, BW, DIM, or MY.

\section{DISCUSSION}

The diets included in our study comprised a large variety of feeds. Major ingredients, however, were corn 
Table 3. The full and final multiple linear regression models (after removal of nonsignificant predictors) for predicting energy efficiency (Eeff; \%), nitrogen efficiency (Neff; \%), and the Neff:Eeff ratio ${ }^{1,2}$

\begin{tabular}{|c|c|c|c|c|c|c|c|c|c|c|c|c|c|}
\hline Variable & Intercept & $\begin{array}{c}\text { NDF } \\
(\% \text { of DM) }\end{array}$ & $\begin{array}{c}\text { ADF } \\
(\% \text { of } \mathrm{DM})\end{array}$ & $\begin{array}{c}\mathrm{DE} \\
\text { (Mcal } / \mathrm{kg} \\
\text { of DM) }\end{array}$ & $\begin{array}{l}\text { DCP } \\
\text { (\% of } \\
\text { DM) }\end{array}$ & $\begin{array}{c}\mathrm{PCO} \\
(\%)\end{array}$ & $\begin{array}{l}\mathrm{PCO}^{2} \\
(\% / 000)\end{array}$ & $\begin{array}{c}\text { MY } \\
(\mathrm{kg} / \mathrm{d})\end{array}$ & $\begin{array}{c}\mathrm{DMI} \\
(\mathrm{kg} \text { of } \mathrm{DM} / \mathrm{d})\end{array}$ & $\begin{array}{c}\text { BW } \\
(\mathrm{kg} / \mathrm{cow})\end{array}$ & $\begin{array}{c}\text { DIM } \\
\text { (d) }\end{array}$ & $\mathrm{AIC}$ & $\mathrm{R}^{2}$ \\
\hline \multirow[t]{2}{*}{ Eeff } & $\begin{array}{l}34.03^{*} \\
(0.49)\end{array}$ & $\begin{array}{c}-0.13 \\
(0.08)\end{array}$ & $\begin{array}{c}-0.02 \\
(0.10)\end{array}$ & - & $\begin{array}{c}-0.07 \\
(0.12)\end{array}$ & $\begin{array}{r}-0.19^{*} \\
(0.03)\end{array}$ & \multirow{4}{*}{$\begin{array}{r}-0.002^{*} \\
(0.003)\end{array}$} & - & - & $\begin{array}{c}0.01 \\
(0.01)\end{array}$ & $\begin{array}{c}-0.01 \\
(0.01)\end{array}$ & 938 & 0.88 \\
\hline & $\begin{array}{c}34.09^{*} \\
(0.51)\end{array}$ & - & $\begin{array}{c}-0.15^{*} \\
(0.08)\end{array}$ & - & - & & & - & - & - & - & 933 & 0.88 \\
\hline \multirow[t]{2}{*}{ Neff } & $\begin{array}{l}43.77^{*} \\
(1.00)\end{array}$ & \multirow[t]{2}{*}{$\begin{array}{c}0.14 \\
(0.20)\end{array}$} & $\begin{array}{r}-0.69^{*} \\
(0.26)\end{array}$ & $\begin{array}{r}-8.53^{*} \\
(2.73)\end{array}$ & \multirow[t]{2}{*}{ - } & \multirow[t]{2}{*}{$\begin{array}{c}0.09 \\
(0.08)\end{array}$} & & - & \multirow[t]{2}{*}{ - } & \multirow{2}{*}{$\begin{array}{c}-0.01 \\
(0.01) \\
-\end{array}$} & \multirow{2}{*}{$\begin{array}{c}-0.02 \\
(0.01) \\
-\end{array}$} & 1,284 & 0.79 \\
\hline & $\begin{array}{l}43.69^{*} \\
(0.98)\end{array}$ & & $\begin{array}{r}-0.56^{*} \\
(0.18)\end{array}$ & $\begin{array}{r}-6.67^{*} \\
(2.24)\end{array}$ & & & & - & & & & 1,254 & 0.79 \\
\hline \multirow[t]{2}{*}{ Neff:Eeff } & $\begin{array}{l}1.25^{*} \\
(0.02)\end{array}$ & \multirow[t]{2}{*}{$\begin{array}{r}-2 \mathrm{E}-04 \\
(0.005)\end{array}$} & $\begin{array}{c}-0.02^{*} \\
(0.006)\end{array}$ & - & \multirow[t]{2}{*}{ - } & \multirow[t]{2}{*}{$\begin{array}{c}0.004^{*} \\
(0.002)\end{array}$} & & $\begin{array}{c}-0.02^{*} \\
(0.004)\end{array}$ & \multirow[t]{2}{*}{$\begin{array}{c}0.007 \\
(0.006)\end{array}$} & \multirow[t]{2}{*}{$\begin{array}{c}2 \mathrm{E}-04 \\
(4 \mathrm{E}-04)\end{array}$} & \multirow[t]{2}{*}{$\begin{array}{c}0.001 * \\
(0.001)\end{array}$} & -188 & 0.70 \\
\hline & $\begin{array}{l}1.25^{*} \\
(0.02)\end{array}$ & & $\begin{array}{c}-0.02^{*} \\
(0.004)\end{array}$ & - & & & $\begin{array}{c}3.98 \mathrm{E}-05^{*} \\
(1.96 \mathrm{E}-05)\end{array}$ & & & & & -197 & 0.64 \\
\hline
\end{tabular}

${ }^{1}$ For each efficiency variable, the estimates of intercept and prediction coefficients are given (with the SE of these estimates in parentheses). All predictions were significantly different from 0 at least at the level $P<0.05$. Prediction variables were mean centered.

${ }^{2} \mathrm{DE}=$ digestible energy content of the diet; $\mathrm{DCP}=$ digestible $\mathrm{CP} ; \mathrm{PCO}=$ proportion of concentrate in the diet; $\mathrm{PCO}{ }^{2}=\mathrm{squared} \mathrm{PCO} ; \mathrm{MY}=$ milk yield $; \mathrm{AIC}=\mathrm{Akaike}$ information criterion.

${ }^{*} P<0.05$.
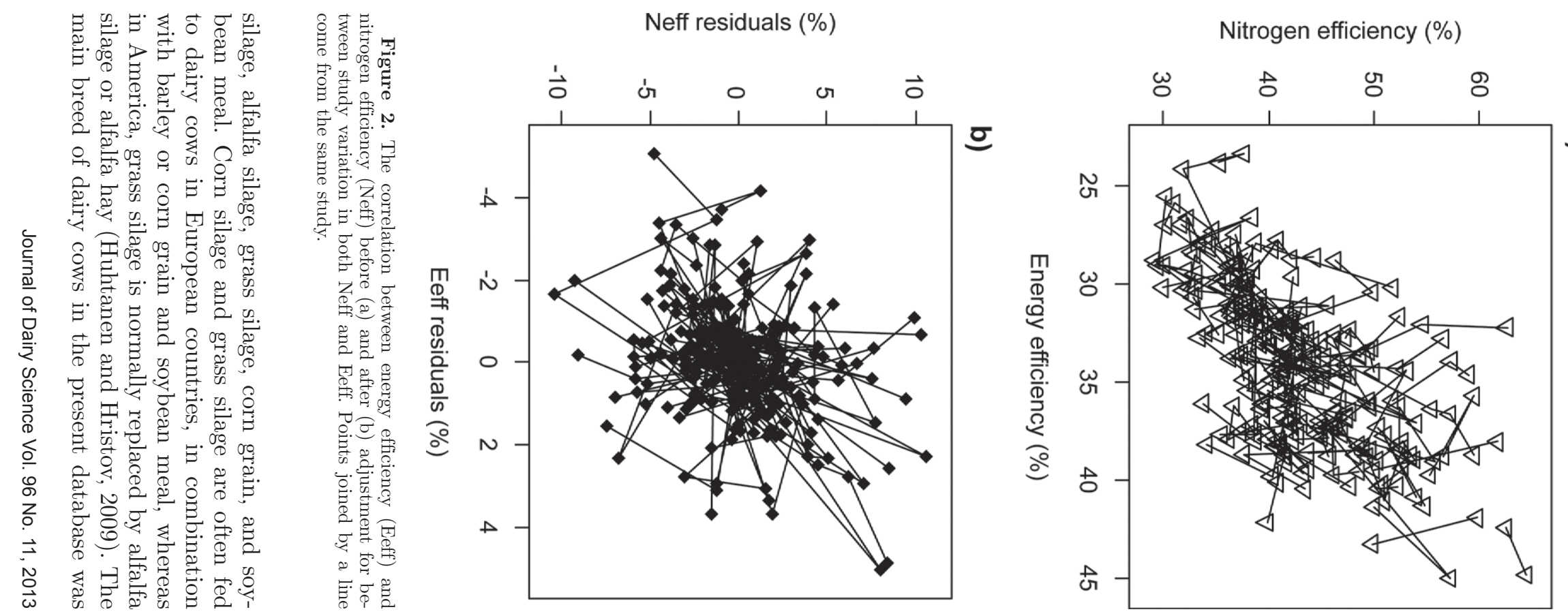


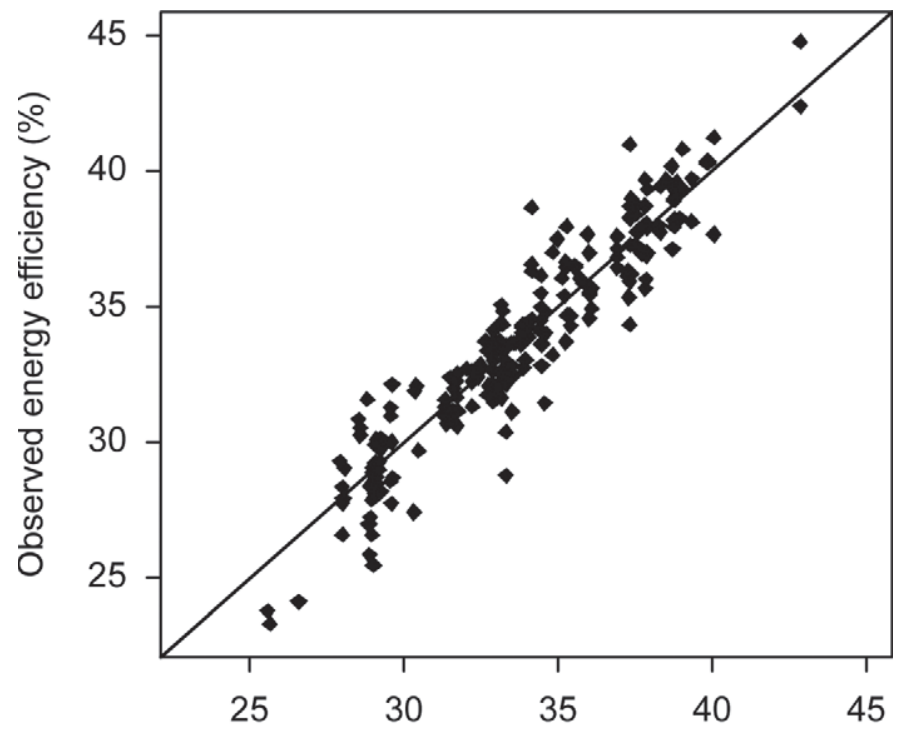

Fitted energy efficiency (\%)

Figure 3. Plot of observed versus predicted values of the model predicting energy efficiency.

Holstein-Friesian. Moreover, it should be noticed that approximately $70 \%$ of data in this study came from North America. The results from this meta-analysis are, therefore, most applicable to Holstein cows fed corn silage, combined with alfalfa silage/hay or grass silage, corn grain, and soybean meal-based diets.

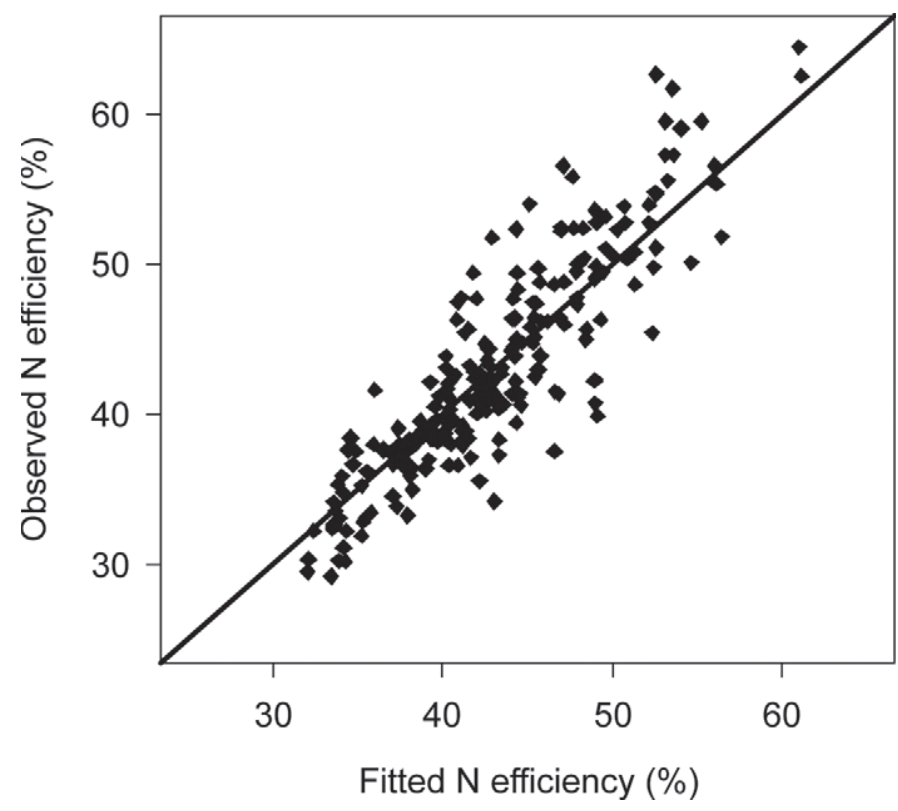

Figure 4. Plot of observed versus predicted values of the model predicting $\mathrm{N}$ efficiency.

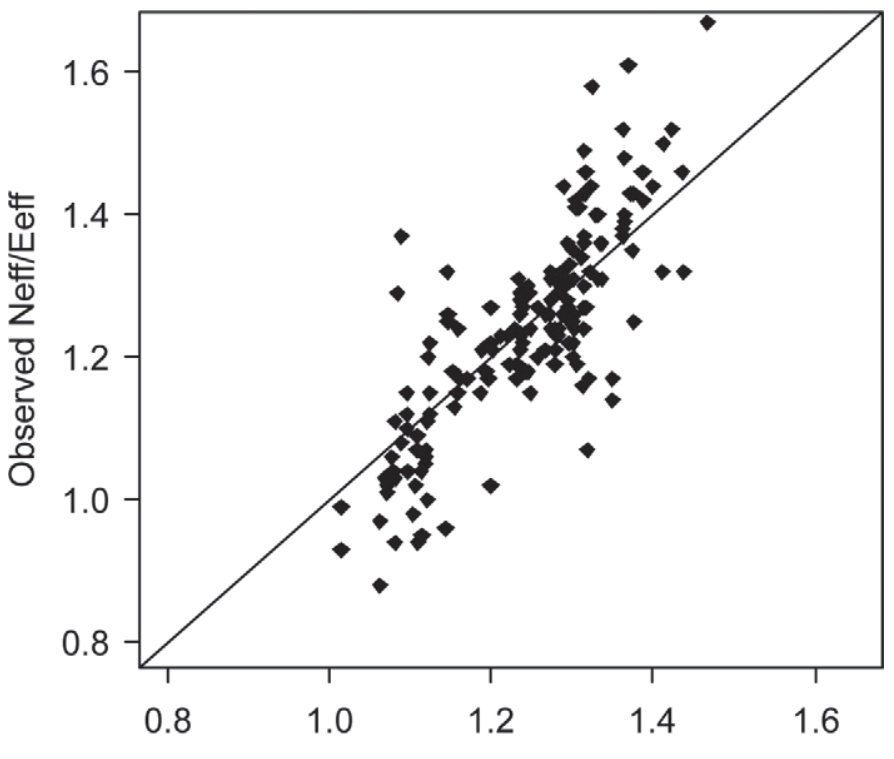

Fitted Neff/Eeff

Figure 5. Plot of observed versus predicted values of the model predicting the $\mathrm{N}$ efficiency:energy efficiency (Neff:Eeff) ratio.

Regarding the chemical composition of the diets, the data showed a large variation in protein, energy, and fiber fractions. The average concentration of DCP was $11.08 \%$. In the literature, most experiments report CP (Colmenero and Broderick, 2006; Brito and Broderick, 2007; Cabrita et al., 2007; Broderick et al., 2009) and MP (Blouin et al., 2002; Raggio et al., 2004; Wang et al., 2007), rather than digestible protein. In terms of $\mathrm{CP}$, the range in our study is in agreement with Huhtanen and Hristov (2009). In their meta-analysis of 425 feeding trials, dietary $\mathrm{CP}$ concentrations of 17.80 and $16.50 \%$ were reported for North America and Northern Europe, respectively. The average concentrations of NDF and ADF were 30.89 and $18.70 \%$, respectively. Similar results have been found in other meta-analyses (Hristov et al., 2004; Ferraretto et al., 2013). The average value of DE was $3.16 \mathrm{Mcal} / \mathrm{kg}$ of DM; this is consistent with the report of Hristov et al. (2005), on the basis of $\mathrm{NE}_{\mathrm{L}}$, in which lactating cows received an average of $37.9 \mathrm{Mcal}$ of $\mathrm{NE}_{\mathrm{L}} / \mathrm{d}$.

The efficiencies of digestible energy and nitrogen usage of lactating dairy cows were found to be, on average, 34.09 and $42.63 \%$, respectively, indicating approximately $60 \%$ losses of energy and nitrogen as gases, urine, or heat increment. VandeHaar and StPierre (2006) reported a value of Eeff varying from 17 to $20.5 \%$ for cows from first to third lactation, when calculated on a gross-energy basis. Nitrogen efficiencies, computed as protein in milk/CP intake, ranging from 26 to $30 \%$ have been commonly reported (Castillo et al., 2001; Brito and Broderick, 2006; Broderick et 
al., 2009). Tamminga and Verstegen (1996) indicated that, generally, $70 \%$ of nitrogen intake is excreted in feces and urine. The difference between digestive and gross efficiencies of energy and nitrogen usage can be attributed to the fecal losses. The inefficiency of DE and nitrogen usage is normally related to the presence of indigestible fiber (West et al., 1997) and the imbalance in the carbohydrate:protein ratio in the rumen (Castillo et al., 2001). This imbalance impairs the rate of microbial synthesis, resulting in a low rate of fiber and protein digestion, and consequently a high rate of ammonia being excreted into the environment (Kebreab et al., 2001). A diet with an adequate energy-toprotein ratio is, therefore, of importance to maximize animal efficiency (Hoover and Stokes, 1991). In the present study, experiments with low Eeff and Neff were generally related to either high NDF $(\approx 40 \%$ of DM; da Silva et al., 2007; Vander Pol et al., 2008) or high DCP ( $\approx 13.24 \%$ of DM; Broderick, 1992; Wattiaux et al., 1994; Groff and Wu, 2005). Additionally, the habit of feeding dairy cows high dietary protein to ensure maximal milk production could also be a cause of such a low Neff (VandeHaar and St-Pierre, 2006). Indeed, the economic cost in the form of milk lost due to underfeeding protein is far more than the cost of overfeeding protein as a margin of safety. In case of an excess of dietary protein, the nitrogen usage efficiency decreases sharply and a significant amount of $\mathrm{N}$ is lost through feces, gases, and urine (Tamminga, 1992). Therefore, research efforts should concentrate on finding ways to produce a high quantity and quality of milk with as low a dietary protein content as possible.

\section{Nutritional Factors Affecting Eeff and Neff}

Various nutritional factors have been cited in the literature that affect feed efficiency: for example, forage:concentrate ratio (Aguerre et al., 2011), carbohydrate:protein ratio (Aldrich et al., 1993), protein concentration (Cabrita et al., 2007; Broderick et al., 2009), and supplement of RUP (Broderick et al., 2008). Our meta-analysis shows that ADF and PCO were significantly associated with Eeff, whereas Neff was significantly associated with $\mathrm{ADF}$ and $\mathrm{DE}$.

The negative effect of ADF on FE could be attributed to decreasing the availability of digested nutrients for animals fed diets containing high fiber content (Allen, 2000; Tjardes et al., 2002). Highly fibrous feeds tend to fill up the rumen quickly, but because they are slowly digested and passed, they limit DMI, milk production, and hence FE (Yang and Beauchemin, 2006). Moreover, highly fibrous feeds contain a limited amount of energy to support microbial growth/synthesis (Jetana et al., 2000). A diet containing an appropriate amount of fi- ber, however, is of importance to avoid rumen acidosis and to maximize microbial growth, rumen health, and subsequently animal efficiency. These considerations would suggest a nonlinear relationship between ADF and Eeff and Neff. However, the residual plots of the models, using ADF individually for predicting Eeff and Neff (figures not shown), do not support this idea, as no discernible pattern could be observed. It would be expected that, in a low-PCO diet, an increasing $\mathrm{PCO}$ improves Eeff by increasing the available energy to support microbial synthesis, but a too high-PCO diet might result in acidosis, which impairs animal performance and Eeff. Feeding cows high-PCO diets may also alter nutrient partitioning (i.e., more to adipose tissues) and subsequently reduces Eeff, as computed in the current study. However, Table 3 indicates a linearly negative correlation between PCO and Eeff in the full model. Although ADF and PCO are to some extent correlated $(\mathrm{r}=0.2)$, we suspected that they were reflecting different aspects: ADF indexing the digestible energy content of the diet and PCO indexing the risk of acidosis. Therefore, to separate the effect of ADF and PCO on Eeff, we decided to split the data based on $\mathrm{ADF}$. The idea was to isolate a part where the likelihood of rumen acidosis is very low (i.e., high ADF), and a part with high risk of acidosis (i.e., low ADF). Such splitting allowed us to look at the effect of PCO on Eeff in these 2 situations, and it revealed that a significant negative effect of PCO on Eeff was only present in the low-ADF $(\leq 21 \%)$ subset of data (Figure 6$)$. This motivated us to incorporate a curvilinear effect of PCO on Eeff in the model, which was done by including a quadratic term. Statistically, such a negative regression coefficient of $\mathrm{PCO}^{2}$ in Table 3 implies that Eeff was positively affected by low PCO, but negatively affected by high PCO. Agle et al. (2010) observed a decrease in $\mathrm{FE}$, computed as $\mathrm{NE}_{\mathrm{L}}$, in high- versus low-PCO diets: 58.3 and $62.9 \%$, respectively. Feeding cows high PCO (e.g., $65-70 \%$ of DM) might result in a decrease in fiber digestibility and fat yield (Moorby et al., 2006). The current study shows that a high PCO in the diet negatively affected Eeff, which could be a consequence of acidosis (VandeHaar and St-Pierre, 2006). However, in a diet with low concentrate (i.e., high fiber) content, Eeff was negatively and dominantly affected by ADF. Our study also indicates that feeding dairy cows highPCO diets resulted in no significant improvement in Neff. This result is consistent with Agle et al. (2010), who reported an only marginally improved Neff when PCO increased from 20 to $60 \%$.

It is important to also be aware that feeding dairy cows a high-PCO diet might alter the partition of nutrients. A high-digestible-carbohydrate diet is expected to result in an increased production of propionate in 
the rumen (Sutton et al., 2003; Friggens et al., 2004). Propionate is absorbed and metabolized by the liver to glucose and triggers an insulin response (Ingvartsen and Andersen, 2000), which subsequently stimulates the lipogenesis and inhibits the release of $\mathrm{FA}$ from

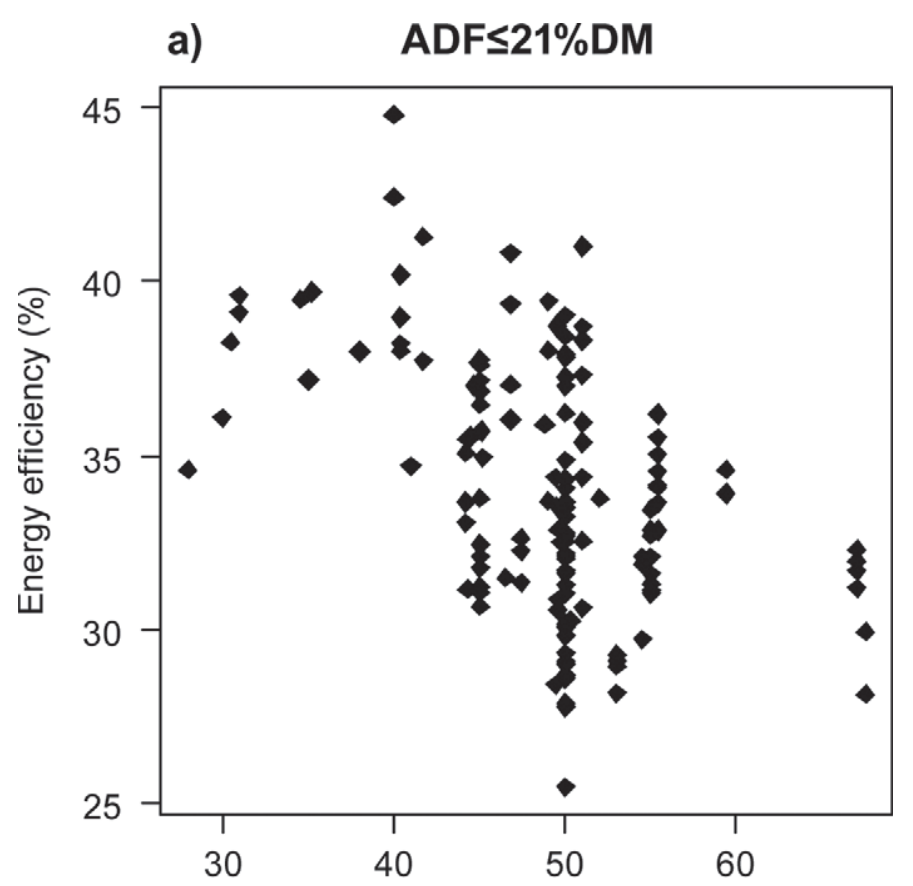

b) $\quad A D F>21 \% D M$

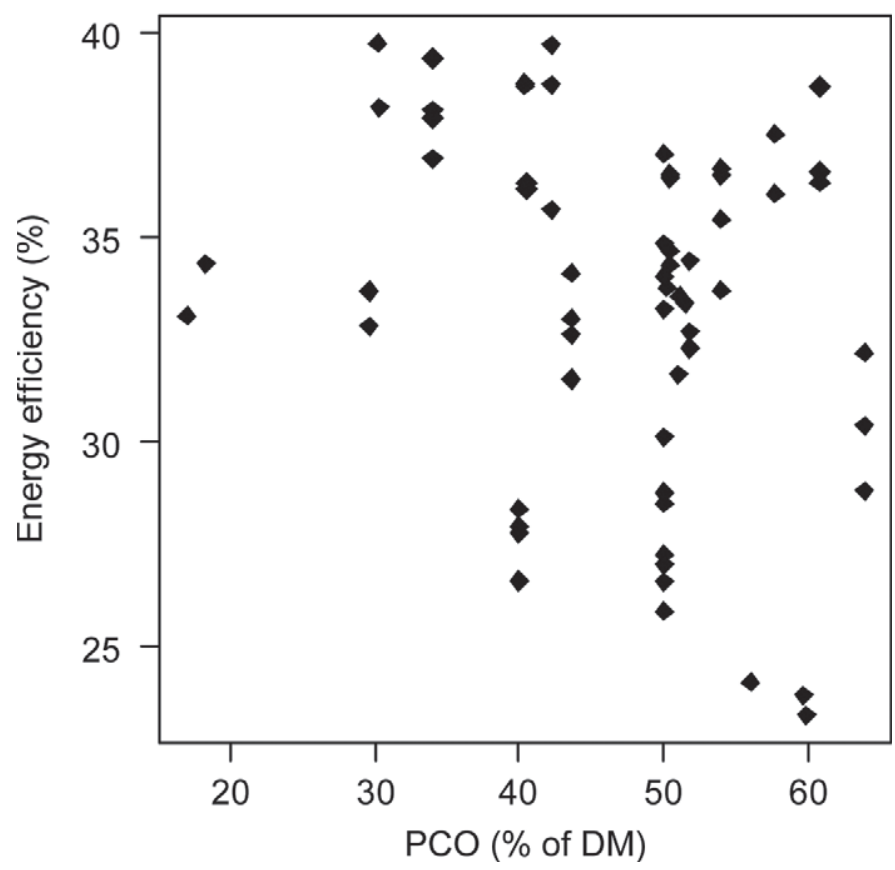

Figure 6. The effect of the proportion of concentrate (PCO) in the diet on energy efficiency for 2 subsets of data: ADF $\leq 21 \%$ of DM and $\mathrm{ADF} \geq 21 \%$ of $\mathrm{DM}$. adipose tissue (lipolysis; Chilliard et al., 2000). Thus, feeding animals a high-PCO diet may result in more nutrients being partitioned to body tissue rather than milk production, and a decrease in efficiencies (calculated as milk/feed).

\section{Relationship Between Eeff and Neff}

Acid detergent fiber and PCO were the only significant feed factors affecting the Neff:Eeff ratio, which is consistent with the separate regressions for each efficiency independently. This suggests that, from a nutritional point of view, a model to predict Eeff could be used to predict Neff without the need to building 2 separate models (i.e., Neff could be considered as an add-on in a model of energy-based efficiency). The routine correlation between these 2 efficiencies [0.62 in the present study and 0.90 in Wheadon et al. (2012)] is, in part, due to the presence of both MY and DMI in the calculation of both efficiencies. However, it is also in part attributable to the phenomenon of dilution of maintenance, as both energy and nitrogen requirements exist for maintenance. Our study further consolidates this by showing that both efficiencies are affected by the same nutritional factors.

\section{Animal Factors Affecting Eeff and Neff}

As stated by Blake and Custodio (1984), FE depends not only on diets but also on the genotypes, physiological states of the animals, and their possible interaction. Clear differences exist in nutrient partitioning and $\mathrm{FE}$ between genotypes of cows (e.g., high- versus low-genetic merit), stages of lactation, and parities (Veerkamp, 1998; Dillon et al., 2003; Friggens et al., 2011). However, Table 3 shows that the current type of transverse database obtained from the literature is not appropriate to fully incorporate the effect of animal factors on FE. Body weight and DIM were the only factors possible to include (with the exception of MY and DMI, which were purposely excluded). Indeed, most of the studies in the literature focus on the effect of nutritional factors (e.g., dietary protein, fiber concentration, and dietary energy concentration; Castillo et al., 2001; Colmenero and Broderick, 2006; Yang and Beauchemin, 2006), with little focus on the effects of breed, parity, BW, or lactation period on Eeff and Neff (Britt et al., 2003, Prendiville et al., 2009). Other types of data (e.g., longitudinal) would be more appropriate to look at the effects of animal factors on FE.

In the present study, we found no significant effect of BW on Eeff or Neff. The significant correlations between BW, DMI, and MY (Table 3) indicate that larger animals ate more feed and produced more milk. 
However, they also had a higher maintenance requirement, which could explain the insignificant effect of BW on FE. Veerkamp (1998) pointed out that if 2 cows of equal BW are compared, the cow with $25 \%$ more MY will have a 10 to $15 \%$ greater $\mathrm{FE}$, whereas if 2 cows of equal MY are compared, the cow with $25 \%$ less BW will have a 10 to $12 \%$ higher FE. Thus, selection for smaller animals that have the same MY may represent a strategy for improving $\mathrm{FE}$ and reducing the environmental impact. Contrary to previous reports (Veerkamp, 1998; Britt et al., 2003), the current meta-analysis found no significant effect of DIM on FE. This probably reflects the shortage of data in early or late lactation, although it is known cows mobilize body reserves in early lactation to support milk production, which affects the results of FE. Cows that mobilize more body reserves in early lactation seem to be more efficient because the usual definition of $\mathrm{FE}$ does not consider nutrients from such a mobilization (Connor et al., 2012). However, high rates of mobilization have been associated with reduced longevity of animals (Rauw et al., 1998) probably via increased problems of fertility (Pryce et al., 2004; Berry et al., 2008) and health (Oltenacu and Algers, 2005), which would reduce the benefit of improved FE. Thus, a better predictive capability and a biological understanding are needed of how a cow partitions her nutritional resources between life functions. Indeed, if FE is considered over the lifespan of animals, then the extent to which nutrients partitioned to the vital functions, such as health and fertility, is important (Friggens et al., 2011).

\section{CONCLUSIONS}

This meta-analysis shows that ADF, PCO, and DE were the common nutritional factors affecting feed efficiency. The Eeff:Neff ratio, however, was affected by the ADF and PCO content of feed only. The strong correlation between Eeff and Neff results indicates a possibility to maximize $\mathrm{FE}$ in terms of both energy and nitrogen at the same time. In other words, an improvement in Eeff would also mean an improvement in Neff. The current study also shows that these types of transverse data are not sufficient to study the effect of animal factors on FE. Longitudinal measurements per animal would be more appropriate.

\section{ACKNOWLEDGMENTS}

The authors gratefully acknowledge the financial support of the GreenhouseMilk project. The GreenhouseMilk project is a Marie Curie Initial Training Network, funded by the European Commission, Framework 7. We thank D. Sauvant (UMR Physiologie de la Nutrition et
Alimentation, INRA-AgroParisTech, Paris, France) for his assistance in building the database.

\section{REFERENCES}

Agle, M., A. N. Hristov, S. Zaman, C. Schneider, P. M. Ndegwa, and V. K. Vaddella. 2010. Effect of dietary concentrate on rumen fermentation, digestibility, and nitrogen losses in dairy cows. J. Dairy Sci. 93:4211-4222.

Aguerre, M. J., M. A. Wattiaux, J. M. Powell, G. A. Broderick, and C. Arndt. 2011. Effect of forage-to-concentrate ratio in dairy cow diets on emission of methane, carbon dioxide, and ammonia, lactation performance, and manure excretion. J. Dairy Sci. 94:30813093.

Aldrich, J. M., L. D. Muller, G. A. Varga, and L. C. Griel Jr. 1993. Nonstructural carbohydrate and protein effects on rumen fermentation, nutrient flow, and performance of dairy Cows. J. Dairy Sci. 76:1091-1105.

Allen, M. S. 2000. Effects of diet on short-term regulation of feed intake by lactating dairy cattle. J. Dairy Sci. 83:1598-1624.

Berry, D. P., J. R. Roche, and M. P. Coffey. 2008. Body condition score and fertility-More than just a feeling. Pages 107-118 in Fertility in Dairy Cows: Bridging the Gaps. M. D. Royal, N. C. Friggens, and R. F. Smith, ed. British Society of Animal Science, Cambridge University Press, Cambridge, UK.

Blake, R. W., and A. A. Custodio. 1984. Feed efficiency: A composite trait of dairy cattle. J. Dairy Sci. 67:2075-2083.

Blouin, J. P., J. F. Bernier, C. K. Reynolds, G. E. Lobley, P. Dubreuil, and H. Lapierre. 2002. Effect of supply of metabolizable protein on splanchnic fluxes of nutrients and hormones in lactating dairy cows. J. Dairy Sci. 85:2618-2630.

Brito, A. F., and G. A. Broderick. 2006. Effect of varying dietary ratios of alfalfa silage to corn silage on production and nitrogen utilization in lactating dairy cows. J. Dairy Sci. 89:3924-3938.

Brito, A. F., and G. A. Broderick. 2007. Effects of different protein supplements on milk production and nutrient utilization in lactating dairy cows. J. Dairy Sci. 90:1816-1827.

Britt, J. S., R. C. Thomas, N. C. Speer, and M. B. Hall. 2003. Efficiency of converting nutrient dry matter to milk in Holstein herds. J. Dairy Sci. 86:3796-3801.

Broderick, G. A. 1992. Relative value of fish meal versus solvent soybean meal for lactating dairy cows fed alfalfa silage as sole forage. J. Dairy Sci. 75:174-183.

Broderick, G. A., M. J. Stevenson, and R. A. Patton. 2009. Effect of dietary protein concentration and degradability on response to rumen-protected methionine in lactating dairy cows. J. Dairy Sci. 92:2719-2728.

Broderick, G. A., M. J. Stevenson, R. A. Patton, N. E. Lobos, and J. J. Olmos Colmenero. 2008. Effect of supplementing rumen-protected methionine on production and nitrogen excretion in lactating dairy cows. J. Dairy Sci. 91:1092-1102.

Brody, S. 1945. Bioenergetics and Growth. Rheinhold Publishing Corp., New York, NY.

Cabrita, A. R. J., R. J. B. Bessa, S. P. Alves, R. J. Dewhurst, and A. J. M. Fonseca. 2007. Effects of dietary protein and starch on intake, milk production, and milk fatty acid profiles of dairy cows fed corn silage-based diets. J. Dairy Sci. 90:1429-1439.

Castillo, A. R., E. Kebreab, D. E. Beever, J. H. Barbi, J. D. Sutton, H. C. Kirby, and J. France. 2001. The effect of energy supplementation on nitrogen utilization in lactating dairy cows fed grass silage diets. J. Anim. Sci. 79:240-246.

Chilliard, Y., A. Ferlay, Y. Faulconnier, M. Bonnet, J. Rouel, and F. Bocquier. 2000. Adipose tissue metabolism and its role in adaptations to undernutrition in ruminants. Proc. Nutr. Soc. 59:127134.

Colmenero, J. J. O., and G. A. Broderick. 2006. Effect of dietary crude protein concentration on milk production and nitrogen utilization in lactating dairy cows. J. Dairy Sci. 89:1704-1712.

Connor, E. E., J. L. Hutchison, K. M. Olson, and H. D. Norman. 2012. Opportunities for improving milk production efficiency in dairy cattle. J. Anim. Sci. 90:1687-1694. 
da Silva, D. C., G. T. Santos, A. F. Branco, J. C. Damasceno, R. Kazama, M. Matsushita, J. A. Horst, W. B. R. dos Santos, and H. V. Petit. 2007. Production performance and milk composition of dairy cows fed whole or ground flaxseed with or without monensin. J. Dairy Sci. 90:2928-2936.

Dillon, P., S. Snijders, F. Buckley, B. Harris, P. O'Connor, and J. F. Mee. 2003. A comparison of different dairy cow breeds on a seasonal grass-based system of milk production: 2. Reproduction and survival. Livest. Prod. Sci. 83:35-42.

Faraway, J. J. 2009. Linear Models with R. Chapman \& Hall/CRC texts in statistical science series. CRC Press, Boca Raton, FL.

Ferraretto, L. F., P. M. Crump, and R. D. Shaver. 2013. Effect of cereal grain type and corn grain harvesting and processing methods on intake, digestion, and milk production by dairy cows through a meta-analysis. J. Dairy Sci. 96:533-550.

Friggens, N. C., J. B. Andersen, T. Larsen, O. Aaes, and R. J. Dewhurst. 2004. Priming the dairy cow for lactation: A review of dry cow feeding strategies. Anim. Res. 53:453-473.

Friggens, N. C., L. Brun-Lafleur, P. Faverdin, D. Sauvant, and O. Martin. 2011. Advances in predicting nutrient partitioning in the dairy cow: Recognizing the central role of genotype and its expression through time. Animal 7(Suppl. 1):89-101.

Groff, E. B., and Z. Wu. 2005. Milk production and nitrogen excretion of dairy cows fed different amounts of protein and varying proportions of alfalfa and corn silage. J. Dairy Sci. 88:3619-3632.

Herd, R. M., and P. F. Arthur. 2009. Physiological basis for residual feed intake. J. Anim. Sci. 87:E64-E71.

Hoover, W. H., and S. R. Stokes. 1991. Balancing carbohydrates and proteins for optimum rumen microbial yield. J. Dairy Sci. 74:3630-3644.

Hristov, A. N., W. J. Price, and B. Shafii. 2004. A meta-analysis examining the relationship among dietary factors, dry matter intake, and milk and milk protein yield in dairy cows. J. Dairy Sci. $87: 2184-2196$.

Hristov, A. N., W. J. Price, and B. Shafii. 2005. A meta-analysis on the relationship between intake of nutrients and body weight with milk volume and milk protein yield in dairy cows. J. Dairy Sci. $88: 2860-2869$.

Huhtanen, P., and A. N. Hristov. 2009. A meta-analysis of the effects of dietary protein concentration and degradability on milk protein yield and milk $\mathrm{N}$ efficiency in dairy cows. J. Dairy Sci. 92:3222-3232.

Ingvartsen, K. L., and J. B. Andersen. 2000. Integration of metabolism and intake regulation: A review focusing on periparturient animals. J. Dairy Sci. 83:1573-1597.

INRA (Institut national de la recherche agronomique). 1988. Alimentation des bovins, ovins et caprins. Tables INRA 1988. Édition Quae, Paris, France.

INRA (Institut national de la recherche agronomique). 2010. Alimentation des bovins, ovins et caprins. Besoin des animaux - Valeurs des aliments. Mise à jour 2010. Tables INRA 2010. Édition Quae, Paris, France.

Jetana, T., N. Abdullah, R. A. Halim, S. Jalaludin, and Y. W. Ho. 2000. Effects of energy and protein supplementation on microbial-N synthesis and allantoin excretion in sheep fed guinea grass. Anim. Feed Sci. Technol. 84:167-181.

Kebreab, E., J. France, D. E. Beever, and A. R. Castillo. 2001. Nitrogen pollution by dairy cows and its mitigation by dietary manipulation. Nutr. Cycl. Agroecosyst. 60:275-285.

Koch, R. M., L. A. Swiger, D. Chambers, and K. E. Gregory. 1963. Efficiency of feed use in beef cattle. J. Anim. Sci. 22:486-494.

Martin, O., and D. Sauvant. 2002. Metaanalysis of input/output kinetics in lactating dairy cows. J. Dairy Sci. 85:3363-3381.

McNaughton, L. R., and J. E. Pryce. 2007. Metabolic feed efficiencyOpportunities for selection in dairy cows. Proc. N.Z. Soc. Anim. Prod. 67:392-398.

Moorby, J. M., R. J. Dewhurst, R. T. Evans, and J. L. Danelón. 2006. Effects of dairy cow diet forage proportion on duodenal nutrient supply and urinary purine derivative excretion. J. Dairy Sci. 89:3552-3562.
Moore, S. S., F. D. Mujibi, and E. L. Sherman. 2009. Molecular basis for residual feed intake in beef cattle. J. Anim. Sci. 87:E41-E47.

Ngwerume, F., and I. L. Mao. 1992. Estimation of residual energy intake for lactating cows using an animal model. J. Dairy Sci. 75:2283-2287.

Nousiainen, J., M. Rinne, and P. Huhtanen. 2009. A meta-analysis of feed digestion in dairy cows. 1 . The effects of forage and concentrate factors on total diet digestibility. J. Dairy Sci. 92:5019-5030.

NRC. 2001. Nutrient Requirements of Dairy Cattle. 7th rev. ed. National Academies Press, Washington, DC.

Oltenacu, P. A., and B. Algers. 2005. Selection for increased production and the welfare of dairy cows: Are new breeding goals needed? Ambio 34:311-315.

Prendiville, R., K. M. Pierce, and F. Buckley. 2009. An evaluation of production efficiencies among lactating Holstein-Friesian, Jersey, and Jersey $\times$ Holstein-Friesian cows at pasture. J. Dairy Sci. 92:6176-6185.

Pryce, J. E., M. D. Royal, P. C. Garnsworthy, and I. L. Mao. 2004. Fertility in the high-producing dairy cow. Livest. Prod. Sci. $86: 125-135$.

Raggio, G., D. Pacheco, R. Berthiaume, G. E. Lobley, D. Pellerin, G. Allard, P. Dubreuil, and H. Lapierre. 2004. Effect of level of metabolizable protein on splanchnic flux of amino acids in lactating dairy cows. J. Dairy Sci. 87:3461-3472.

Rauw, W. M., E. Kanis, E. N. Noordhuizen-Stassen, and F. J. Grommers. 1998. Undesirable side effects of selection for high production efficiency in farm animals: A review. Livest. Prod. Sci. 56:15-33.

R Development Core Team. 2012. The GNU Project. The R Project for Statistical Computing. Accessed Jan. 4, 2013. http://www.rproject.org/.

Richardson, E. C., R. M. Herd, J. A. Archer, and P. F. Arthur. 2004 Metabolic differences in Angus steers divergently selected for residual feed intake. Aust. J. Exp. Agric. 44:441-452.

Roseler, D. K., D. G. Fox, A. N. Pell, and L. E. Chase. 1997. Evaluation of alternative equations for prediction of intake for Holstein dairy cows. J. Dairy Sci. 80:864-877.

Sauvant, D., and S. Giger-Reverdin. 2009. Modélisation des interactions digestives et de la production de méthane chez les ruminants. Prod. Anim. 22:375-384.

Sauvant, D., J. M. Perez, and G. Tran. 2004. Tables of composition and nutritional value of feed materials: Pigs, poultry, cattle, sheep, goats, rabbits, horses and fish. Wageningen Academic Publishers, Wageningen, the Netherlands.

Shalloo, L., J. Kennedy, M. Wallace, M. Rath, and P. Dillon. 2004. The economic impact of cow genetic potential for milk production and concentrate supplementation level on the profitability of pasture based systems under different EU milk quota scenarios. J. Agric. Sci. 142:357-369.

Silvey, S. D. 1969. Multicollinearity and imprecise estimation. J. R. Stat. Soc. [Ser A] 31:539-552.

St-Pierre, N. R. 2001. Invited review: Integrating quantitative findings from multiple studies using mixed model methodology. J. Dairy Sci. 84:741-755.

Sutton, J. D., M. S. Dhanoa, S. V. Morant, J. France, D. J. Napper, and E. Schuller. 2003. Rates of production of acetate, propionate and butyrate in the rumen of lactating dairy cows given normal and low-roughage diets. J. Dairy Sci. 86:3620-3633.

Tamminga, S. 1992. Nutrition management of dairy cows as a contribution to pollution control. J. Dairy Sci. 75:345-357.

Tamminga, S., and M. W. A. Verstegen. 1996. Implications of nutrition of animals on environmental pollution. Pages 121-134 in Recent Advances in Animal Nutrition. P. C. Garnsworthy, W. Haresign, and D. J. A. Cole, ed. Nottingham University Press, Nottingham, UK.

Thomassen, M. A., M. A. Dolman, K. J. van Calker, and I. J. M. de Boer. 2009. Relating life cycle assessment indicators to gross value added for Dutch dairy farms. Ecol. Econ. 68:2278-2284.

Tjardes, K. E., D. D. Buskirk, M. S. Allen, N. K. Ames, L. D. Bourquin, and S. R. Rust. 2002. Neutral detergent fiber concentration of corn 
silage and rumen inert bulk influences dry matter intake and ruminal digesta kinetics of growing steers. J. Anim. Sci. 80:833-840.

Tolkamp, B. J. 2010. Efficiency of energy utilisation and voluntary feed intake in ruminants. Animal 4:1084-1092.

VandeHaar, M. J., and N. St-Pierre. 2006. Major advances in nutrition: Relevance to the sustainability of the dairy industry. J. Dairy Sci. 89:1280-1291.

Vander Pol, M., A. N. Hristov, S. Zaman, and N. Delano. 2008. Peas can replace soybean meal and corn grain in dairy cow diets. J. Dairy Sci. 91:698-703.

Veerkamp, R. F. 1998. Selection for economic efficiency of dairy cattle using information on live weight and feed intake: A review. J. Dairy Sci. 81:1109-1119.

Veerkamp, R. F., and G. C. Emmans. 1995. Sources of genetic variation in energetic efficiency of dairy cows. Livest. Prod. Sci. 44:87-97.

Voelker, J. A., G. M. Burato, and M. S. Allen. 2002. Effects of pretrial milk yield on responses of feed intake, digestion, and production to dietary forage concentration. J. Dairy Sci. 85:2650-2661.

Wall, E., G. Simm, and D. Moran. 2010. Developing breeding schemes to assist mitigation of greenhouse gas emissions. Animal 4:366376

Wang, C., J. X. Liu, Z. P. Yuan, Y. M. Wu, S. W. Zhai, and H. W. Ye. 2007. Effect of level of metabolizable protein on milk production and nitrogen utilization in lactating dairy cows. J. Dairy Sci. 90:2960-2965.

Wang, S., G. L. Roy, A. J. Lee, A. J. McAllister, T. R. Batra, C. Y. Lin, J. A. Vesely, J.-M. Wauthy, and K. A. Winter. 1992. Evaluation of various measures of and factors influencing feed efficiency of dairy cattle. J. Dairy Sci. 75:1273-1280.

Wattiaux, M. A., D. K. Combs, and R. D. Shaver. 1994. Lactational responses to ruminally undegradable protein by dairy cows fed diets based on alfalfa silage. J. Dairy Sci. 77:1604-1617.

West, J. W., G. M. Hill, R. N. Gates, and B. G. Mullinix. 1997. Effects of dietary forage source and amount of forage addition on intake, milk yield, and digestion for lactating dairy cows. J. Dairy Sci. 80:1656-1665.

Wheadon, N. W., G. R. Edwards, and R. J. Dewhurst. 2012. Comparison of nitrogen-use efficiency and energy conversion efficiency as measures of feed conversion efficiency in Holstein-Friesian cows over an entire lactation cycle. Adv. Anim. Biosci. 3:142.

Yan, T., C. S. Mayne, F. G. Gordon, M. G. Porter, R. E. Agnew, D. C. Patterson, C. P. Ferris, and D. J. Kilpatrick. 2010. Mitigation of enteric methane emissions through improving efficiency of energy utilization and productivity in lactating dairy cows. J. Dairy Sci. 93:2630-2638

Yang, W. Z., and K. A. Beauchemin. 2006. Increasing the physically effective fiber content of dairy cow diets may lower efficiency of feed use. J. Dairy Sci. 89:2694-2704.

Zamani, P., S. R. Miraei-Ashtiani, and H. Mohammadi. 2008. Genetic parameters of residual energy intake and its correlations with other traits in Holstein dairy cattle. Turk. J. Vet. Anim. Sci. $32: 255-261$.

\section{APPENDIX}

Aguerre, M. J., M. A. Wattiaux, J. M. Powell, G. A. Broderick, and C. Arndt. 2011. Effect of forage-to-concentrate ratio in dairy cow diets on emission of methane, carbon dioxide, and ammonia, lactation performance, and manure excretion. J. Dairy Sci. 94:30813093.

Benchaar, C., H. V. Petit, R. Berthiaume, T. D. Whyte, and P. Y. Chouinard. 2006. Effects of addition of essential oils and monensin premix on digestion, ruminal fermentation, milk production, and milk composition in dairy cows. J. Dairy Sci. 89:4352-4364.

Bernard, J. K., M. C. Calhoun, and S. A. Martin. 1999. Effect of coating whole cottonseed on performance of lactating dairy cows. J. Dairy Sci. 82:1296-1304.

Borucki Castro, S. I., L. E. Phillip, H. Lapierre, P. W. Jardon, and R. Berthiaume. 2008. The relative merit of ruminal undegradable pro- tein from soybean meal or soluble fibre from beet pulp to improve nitrogen utilization in dairy cows. J. Dairy Sci. 91:3947-3957.

Brito, A. F., and G. A. Broderick. 2006. Effect of varying dietary ratios of alfalfa silage to corn silage on production and nitrogen utilization in lactating dairy cows. J. Dairy Sci. 89:3924-3938.

Brito, A. F., and G. A. Broderick. 2007. Effects of different protein supplements on milk production and nutrient utilization in lactating dairy cows. J. Dairy Sci. 90:1816-1827.

Broderick, G. A. 1992. Relative value of fish meal versus solvent soybean meal for lactating dairy cows fed alfalfa silage as sole forage. J. Dairy Sci. 75:174-183.

Broderick, G. A. 1995. Performance of lactating dairy cows fed either alfalfa silage or alfalfa hay as the sole forage. J. Dairy Sci. $78: 320-329$.

Broderick, G. A. 2004. Effect of low level monensin supplementation on the production of dairy cows fed alfalfa silage. J. Dairy Sci. $87: 359-368$.

Broderick, G. A., A. F. Brito, and J. J. O. Colmenero. 2007. Effects of feeding formate-treated alfalfa silage or red clover silage on the production of lactating dairy cows. J. Dairy Sci. 90:1378-1391.

Broderick, G. A., R. G. Koegel, R. P. Walgenbach, and T. J. Kraus. 2002. Ryegrass or alfalfa silage as the dietary forage for lactating dairy cows. J. Dairy Sci. 85:1894-1901.

Broderick, G. A., and R. E. Muck. 2009. Effect of alfalfa silage storage structure and rumen-protected methionine on production in lactating dairy cows. J. Dairy Sci. 92:1281-1289.

Broderick, G. A., M. J. Stevenson, and R. A. Patton. 2009. Effect of dietary protein concentration and degradability on response to rumen-protected methionine in lactating dairy cows. J. Dairy Sci. 92:2719-2728.

Broderick, G. A., M. J. Stevenson, R. A. Patton, N. E. Lobos, and J. J. Olmos Colmenero. 2008. Effect of supplementing rumen-protected methionine on production and nitrogen excretion in lactating dairy cows. J. Dairy Sci. 91:1092-1102.

Cabrita, A. R. J., R. J. B. Bessa, S. P. Alves, R. J. Dewhurst, and A. J. M. Fonseca. 2007. Effects of dietary protein and starch on intake, milk production, and milk fatty acid profiles of dairy cows fed corn silage-based diets. J. Dairy Sci. 90:1429-1439.

Cabrita, A. R. J., R. J. Dewhurst, D. S. P. Melo, J. M. Moorby, and A. J. M. Fonseca. 2011. Effects of dietary protein concentration and balance of absorbable amino acids on productive responses of dairy cows fed corn silage-based diets. J. Dairy Sci. 94:4647-4656.

Cabrita, A. R. J., A. J. M. Fonseca, R. J. Dewhurst, C. V. P. Sampaio, M. F. S. Miranda, G. N. S. Sousa, I. M. F. Miranda, and E. Gomes. 2003. Nitrogen supplementation of corn silages. 1. Effects on feed intake and milk production of dairy cows. J. Dairy Sci. 86:4008-4019.

Cabrita, A. R. J., J. M. P. Vale, R. J. B. Bessa, R. J. Dewhurst, and A. J. M. Fonseca. 2009. Effects of dietary starch source and buffers on milk responses and rumen fatty acid biohydrogenation in dairy cows fed maize silage-based diets. Anim. Feed Sci. Technol. 152:267-277.

Castillo, A. R., E. Kebreab, D. E. Beever, J. H. Barbi, J. D. Sutton, H. C. Kirby, and J. France. 2001. The effect of energy supplementation on nitrogen utilization in lactating dairy cows fed grass silage diets. J. Anim. Sci. 79:240-246.

Charbonneau, E., P. Y. Chouinard, G. Allard, H. Lapierre, and D. Pellerin. 2006. Milk from forage as affected by carbohydrate source and degradability with alfalfa silage-based diets. J. Dairy Sci. 89:283-293.

Charbonneau, E., P. Y. Chouinard, G. Allard, H. Lapierre, and D. Pellerin. 2007. Milk from forage as affected by rumen degradable protein and corn grinding when feeding corn- and alfalfa silagebased diets. J. Dairy Sci. 90:823-832.

Chen, Z. H., G. A. Broderick, N. D. Luchini, B. K. Sloan, and E. Devillard. 2011. Effect of feeding different sources of rumen-protected methionine on milk production and N-utilization in lactating dairy cows. J. Dairy Sci. 94:1978-1988.

Cherney, D. J. R., J. H. Cherney, and L. E. Chase. 2003. Influence of dietary nonfiber carbohydrate concentration and supplementation 
of sucrose on lactation performance of cows fed fescue silage. J. Dairy Sci. 86:3983-3991.

Cherney, D. J. R., J. H. Cherney, and L. E. Chase. 2004. Lactation performance of Holstein cows fed fescue, orchardgrass, or alfalfa silage. J. Dairy Sci. 87:2268-2276.

Christen, K. A., D. J. Schingoethe, K. F. Kalscheur, A. R. Hippen, K. K. Karges, and M. L. Gibson. 2010. Response of lactating dairy cows to high protein distillers grains or 3 other protein supplements. J. Dairy Sci. 93:2095-2104.

Colmenero, J. J. O., and G. A. Broderick. 2006a. Effect of amount and ruminal degradability of soybean meal protein on performance of lactating dairy cows. J. Dairy Sci. 89:1635-1643.

Colmenero, J. J. O., and G. A. Broderick. 2006b. Effect of dietary crude protein concentration on milk production and nitrogen utilization in lactating dairy cows. J. Dairy Sci. 89:1704-1712.

Cope, C. M., A. M. Mackenzie, D. Wilde, and L. A. Sinclair. 2009. Effects of level and form of dietary zinc on dairy cow performance and health. J. Dairy Sci. 92:2128-2135.

Côrtes, C., R. Kazama, D. da Silva-Kazama, C. Benchaar, L. M. Zeoula, G. T. Santos, and H. V. Petit. 2011. Digestion, milk production and milk fatty acid profile of dairy cows fed flax hulls and infused with flax oil in the abomasum. J. Dairy Res. 78:293-300.

da Silva, D. C., G. T. Santos, A. F. Branco, J. C. Damasceno, R. Kazama, M. Matsushita, J. A. Horst, W. B. R. dos Santos, and H. V. Petit. 2007. Production performance and milk composition of dairy cows fed whole or ground flaxseed with or without monensin. J. Dairy Sci. 90:2928-2936.

Dai, X. J., C. Wang, and Q. Zhu. 2011. Milk performance of dairy cows supplemented with rape seed oil, peanut oil, and sunflower seed oil. Czech J. Anim. Sci. 56:181-191.

Davidson, S., B. A. Hopkins, D. E. Diaz, S. M. Bolt, C. Brownie, V. Fellner, and L. W. Whitlow. 2003. Effects of amounts and degradability of dietary protein on lactation, nitrogen utilization, and excretion in early lactation Holstein cows. J. Dairy Sci. 86:16811689.

Donkin, S. S., G. A. Varga, T. F. Sweeney, and L. D. Muller. 1989. Rumen-protected methionine and lysine: Effects on animal performance, milk protein yield, and physiological measures. J. Dairy Sci. 72:1484-1491

Erickson, P. S., M. R. Murphy, and J. H. Clark. 1992. Supplementation of dairy cow diets with calcium salts of long-chain fatty acids and nicotinic acid in early lactation. J. Dairy Sci. 75:1078-1089.

Gehman, A. M., P. J. Kononoff, C. R. Mullins, and B. N. Janicek. 2008. Evaluation of nitrogen utilization and the effects of monensin in dairy cows fed brown midrib corn silage. J. Dairy Sci. 91:288-300.

Givens, D. I., K. E. Kliem, D. J. Humphries, K. J. Shingfield, and R. Morgan. 2009. Effect of replacing calcium salts of palm oil distillate with rapeseed oil, milled or whole rapeseeds on milk fattyacid composition in cows fed maize silage-based diets. Animal 3:1067-1074

Groff, E. B., and Z. Wu. 2005. Milk production and nitrogen excretion of dairy cows fed different amounts of protein and varying proportions of alfalfa and corn silage. J. Dairy Sci. 88:3619-3632.

He, M. L., P. S. Mir, K. A. Beauchemin, M. Ivan, and Z. Mir. 2005. Effects of dietary sunflower seeds on lactation performance and conjugated linoleic acid content of milk. Can. J. Anim. Sci. 85:75-83.

Hristov, A. N., C. Lee, T. Cassidy, M. Long, K. Heyler, B. Corl, and R. Forster. 2011. Effects of lauric and myristic acids on ruminal fermentation, production, and milk fatty acid composition in lactating dairy cows. J. Dairy Sci. 94:382-395.

Hristov, A. N., G. Varga, T. Cassidy, M. Long, K. Heyler, S. K. R. Karnati, B. Corl, C. J. Hovde, and I. Yoon. 2010. Effect of Saccharomyces cerevisiae fermentation product on ruminal fermentation and nutrient utilization in dairy cows. J. Dairy Sci. 93:682-692.

Ipharraguerre, I. R., and J. H. Clark. 2005. Varying protein and starch in the diet of dairy cows. II. Effects on performance and nitrogen utilization for milk production. J. Dairy Sci. 88:2556-2570.

Kalscheur, K. F., R. L. Baldwin VI, B. P. Glenn, and R. A. Kohn. 2006. Milk production of dairy cows fed differing concentrations of rumen-degraded protein. J. Dairy Sci. 89:249-259.
Kalscheur, K. F., J. H. Vandersall, R. A. Erdman, R. A. Kohn, and E. Russek-Cohen. 1999. Effects of dietary crude protein concentration and degradability on milk production responses of early, mid, and late lactation dairy cows. J. Dairy Sci. 82:545-554.

Kliem, K. E., K. J. Shingfield, D. J. Humphries, and D. I. Givens. 2011. Effect of replacing calcium salts of palm oil distillate with incremental amounts of conventional or high oleic acid milled rapeseed on milk fatty acid composition in cows fed maize silage-based diets. Animal 5:1311-1321.

Kristensen, N. B., A. C. Storm, and M. Larsen. 2010. Effect of dietary nitrogen content and intravenous urea infusion on ruminal and portal-drained visceral extraction of arterial urea in lactating Holstein cows. J. Dairy Sci. 93:2670-2683.

Krizsan, S. J., G. A. Broderick, R. E. Muck, C. Promkot, S. Colombini, and Å. T. Randby. 2007. Effect of alfalfa silage storage structure and roasting corn on production and ruminal metabolism of lactating dairy cows. J. Dairy Sci. 90:4793-4804.

Lee, C., A. N. Hristov, K. S. Heyler, T. W. Cassidy, M. Long, B. A. Corl, and S. K. R. Karnati. 2011. Effects of dietary protein concentration and coconut oil supplementation on nitrogen utilization and production in dairy cows. J. Dairy Sci. 94:5544-5557.

Mabjeesh, S. J., J. Galindez, O. Kroll, and A. Arieli. 2000. The effect of roasting nonlinted whole cottonseed on milk production by dairy cows. J. Dairy Sci. 83:2557-2563.

Mäntysaari, P., H. Khalili, J. Sariola, and A. Rantanen. 2007. Use of barley fibre and wet distillers' solubles as feedstuffs for Ayrshire dairy cows. Anim. Feed Sci. Technol. 135:52-65.

Martineau, R., C. Benchaar, H. V. Petit, H. Lapierre, D. R. Ouellet, D. Pellerin, and R. Berthiaume. 2007. Effects of lasalocid or monensin supplementation on digestion, ruminal fermentation, blood metabolites, and milk production of lactating dairy cows. J. Dairy Sci. 90:5714-5725.

Martinez, C. M., Y. H. Chung, V. A. Ishler, K. W. Bailey, and G. A. Varga. 2009. Effects of dietary forage level and monensin on lactation performance, digestibility and fecal excretion of nutrients, and efficiency of feed nitrogen utilization of Holstein dairy cows. J. Dairy Sci. 92:3211-3221.

Mjoun, K., K. F. Kalscheur, A. R. Hippen, and D. J. Schingoethe. 2010a. Performance and amino acid utilization of early lactation dairy cows fed regular or reduced-fat dried distillers grains with solubles. J. Dairy Sci. 93:3176-3191.

Mjoun, K., K. F. Kalscheur, A. R. Hippen, D. J. Schingoethe, and D. E. Little. 2010b. Lactation performance and amino acid utilization of cows fed increasing amounts of reduced-fat dried distillers grains with solubles. J. Dairy Sci. 93:288-303.

Moallem, U., G. Altmark, H. Lehrer, and A. Arieli. 2010. Performance of high-yielding dairy cows supplemented with fat or concentrate under hot and humid climates. J. Dairy Sci. 93:3192-3202.

Mulrooney, C. N., D. J. Schingoethe, K. F. Kalscheur, and A. R. Hippen. 2009. Canola meal replacing distillers grains with solubles for lactating dairy cows. J. Dairy Sci. 92:5669-5676.

Onetti, S. G., S. M. Reynal, and R. R. Grummer. 2004. Effect of alfalfa forage preservation method and particle length on performance of dairy cows fed corn silage-based diets and tallow. J. Dairy Sci. $87: 652-664$

Petit, H. V., R. J. Dewhurst, J. G. Proulx, M. Khalid, W. Haresign, and H. Twagiramungu. 2001. Milk production, milk composition, and reproductive function of dairy cows fed different fats. Can. J. Anim. Sci. 81:263-271.

Rode, L. M., W. Z. Yang, and K. A. Beauchemin. 1999. Fibrolytic enzyme supplements for dairy cows in early lactation. J. Dairy Sci. $82: 2121-2126$

Santos, F. A. P., J. T. Huber, C. B. Theurer, R. S. Swingle, J. M. Simas, K. H. Chen, and P. Yu. 1998. Milk yield and composition of lactating cows fed steam-flaked sorghum and graded concentrations of ruminally degradable protein. J. Dairy Sci. 81:215-220.

Schingoethe, D. J., M. J. Brouk, K. D. Lightfield, and R. J. Baer. 1996. Lactational responses of dairy cows fed unsaturated fat from extruded soybeans or sunflower seeds. J. Dairy Sci. 79:1244-1249. 
Schingoethe, D. J., K. N. Linke, K. F. Kalscheur, A. R. Hippen, D. R. Rennich, and I. Yoon. 2004. Feed efficiency of mid-lactation dairy cows fed yeast culture during summer. J. Dairy Sci. 87:4178-4181.

Tekippe, J. A., A. N. Hristov, K. S. Heyler, T. W. Cassidy, V. D Zheljazkov, J. F. S. Ferreira, S. K. Karnati, and G. A. Varga. 2011. Rumen fermentation and production effects of Origanum vulgare L. leaves in lactating dairy cows. J. Dairy Sci. 94:5065-5079.

Vander Pol, M., A. N. Hristov, S. Zaman, and N. Delano. 2008. Peas can replace soybean meal and corn grain in dairy cow diets. J. Dairy Sci. 91:698-703.

Wang, C., H. Y. Liu, Y. M. Wang, Z. Q. Yang, J. X. Liu, Y. M. Wu, T. Yan, and H. W. Ye. 2010. Effects of dietary supplementation of methionine and lysine on milk production and nitrogen utilization in dairy cows. J. Dairy Sci. 93:3661-3670.
Wang, C., J. X. Liu, Z. P. Yuan, Y. M. Wu, S. W. Zhai, and H. W. Ye. 2007. Effect of level of metabolizable protein on milk production and nitrogen utilization in lactating dairy cows. J. Dairy Sci. 90:2960-2965.

Wattiaux, M. A., D. K. Combs, and R. D. Shaver. 1994. Lactational responses to ruminally undegradable protein by dairy cows fed diets based on alfalfa silage. J. Dairy Sci. 77:1604-1617.

Wattiaux, M. A., and K. L. Karg. 2004. Protein level for alfalfa and corn silage-based diets: I. Lactational response and milk urea nitrogen. J. Dairy Sci. 87:3480-3491.

Weiss, W. P., and D. J. Wyatt. 2006. Effect of corn silage hybrid and metabolizable protein supply on nitrogen metabolism of lactating dairy cows. J. Dairy Sci. 89:1644-1653. 